\title{
Thermal characterization of anaerobic sludges from wastewater treatments applied to biological generation of $\mathbf{H}_{2}$
}

\author{
Lilian Danielle de Moura Torquato ${ }^{1}$ (D) Sônia de Almeida ${ }^{1} \cdot$ José Eduardo de Oliveira $^{2}$. \\ Marisa Spirandeli Crespi ${ }^{1} \cdot$ Sandra Imaculada Maintinguer ${ }^{3,4}$
}

Received: 6 June 2016/ Accepted: 26 October 2016/Published online: 12 November 2016

(C) Akadémiai Kiadó, Budapest, Hungary 2016

\begin{abstract}
A wide variety of organic residues may be used as energy source such as anaerobic sludge from wastewater treatment systems. However, due to inherent differences in composition, the proper characterization of these biomasses is essential to support their reuse through any conversion process. The aim of this study was the employment of thermal analysis techniques (TG/DTG and DTA) to perform the characterization of anaerobic sludges from different wastewater treatment plants (industrial and municipal), which were further applied for biological production of $\mathrm{H}_{2}$. The different profiles observed through thermal characterization support the application of these residues as inocula, confirming their potential for $\mathrm{H}_{2}$ production, while demonstrating the main causes for the different yields obtained ( $\mathrm{mol} \mathrm{H} \mathrm{H}_{2} \mathrm{~mol}^{-1}$ sucrose): 0.9 from sludge of brewery industry and 2.0 from sludge of municipal wastewater treatment plant, corresponding to the overall yields of 10.8 and $25 \%$, respectively. These results confirm the versatility of thermal analysis techniques for
\end{abstract}

Lilian Danielle de Moura Torquato

liliantorquato@yahoo.com.br; litorquato.ibilce@gmail.com

Sandra Imaculada Maintinguer

mainting2008@gmail.com

1 Department of Analytical Chemistry, Institute of Chemistry of Araraquara, UNESP - Univ Estadual Paulista, CP 355, Araraquara, SP 14801-970, Brazil

2 Center for Monitoring and Research of the Quality of Fuels, Biofuels, Crude Oil and Derivatives (CEMPEQC), Institute of Chemistry of Araraquara, UNESP - Univ Estadual Paulista, CP 355, Araraquara, SP 14801-970, Brazil

3 Institute of Research on Bioenergy (IPBEN), UNESP - Univ Estadual Paulista, Rio Claro, SP 13500-230, Brazil

4 University Center of Araraquara (UNIARA), Araraquara, SP 14801-320, Brazil biomass characterization, focused on its application for power generation. It is urgent to adopt more sustainable and cost-effective solutions for their management, considering a large amount of residues daily generated in both treatment processes addressed; therefore, biohydrogen production by anaerobic digestion may be a promising alternative for the reuse of both residues as it promotes their transformation from costly and potentially polluting waste into clean and renewable energy sources. The development of this anaerobic process is even more attractive in countries as Brazil, where the weather conditions are naturally favorable.

Keywords Thermal analysis - Biomass - Brewery industry $\cdot$ Anaerobic sludge $\cdot$ Biohydrogen generation

\section{Introduction}

Preservation and conservation of water resources are among the most discussed topics in the world, deserving numerous constitutional references [1, 2]. The great demand for water and the sewage discharge directly affect the quality of rivers, harming their multiple uses. In the last two decades, there were many efforts for the development of effective technologies to wastewater treatment, which provided remarkable improvements in the quality of treated effluent.

In parallel with this progress, however, there was an increase in problems related to the significant amount of sludge generated and its high cost of disposal, which may exceed $50 \%$ of the overall costs of a wastewater treatment plant. Furthermore, the sludge has a hazardous potential to both the human health and the environment [3] that arises from its improper management, given that its complex 
composition includes pathogens organisms, proteins, lipids, polysaccharides, emerging contaminants, a high load of nitrogen and phosphorus, as well as toxic metals [4].

In Brazil, the sewage sludge disposal was commonly done in landfills. However, this practice has been forbidden from August 2014, given the provisions of Law 12.305 of 2010 (regulated by Decree 7.404 of 2010), establishing the Brazilian National Policy on Solid Waste [5]. Besides the high cost, the disposal of sewage sludge in landfills exacerbates the problem of municipal solid waste management due to its inherent composition. The compliance with this law has required the search for new technologies to treatment and reuse of sludge, being the bioenergy and biofuels production very attractive options.

Besides wastewater treatment, many production processes also generate significant amounts of residue on a day basis. The clarification of gross beer, for instance, is one of the most critical operations units in brewing process, generating large amounts of sludge with hazardous features and high-cost disposal. In Europe, the disposal of brewery industry sludge has an average cost of $170 €$ ton $^{-1}$, which varies according to the process [6]. Beer is the fifth most popular beverage in the world, with an average annual consumption of $23 \mathrm{~L}$ per person. In 2014, the beer worldwide production reached about 1.96 billion hectoliters [7].

The diversification of energy sources through biomass, such as sludge, has become a promising alternative to meet the growing worldwide energy demand, while growing the concerns about the numerous environmental impacts caused by burning fossil fuels [4]. The anaerobic digestion of animal waste is probably the oldest form of energy production from biomass, applied to ensure the local energy supply through methane generation. When the oil crisis erupted in 1970, this technology started gaining more attention [8]. Although more time-consuming compared to thermochemical routes, it does not require a great external demand for energy, increasing the cost-effectiveness of the whole process.

Organic substrates are converted into methane and carbon dioxide by anaerobic digestion in a series of biochemical reactions, resulting from metabolic interactions between groups of microorganisms. During hydrolysis, carbohydrates, proteins, and lipids are converted into simpler molecules, which are consumed by the acidogenic bacteria to produce $\mathrm{H}_{2}$ and $\mathrm{CO}_{2}$. These gaseous products may be consumed by either acetogenic bacteria (to produce acetate) or methanogenic archaea [9], as represented by Eq. (1). Therefore, to promote the generation of $\mathrm{H}_{2}$, the activity of methanogenic archaea must be inhibited $[10,11]$, which is usually obtained through physical or chemical pre-treatment strategies [12].
$\mathrm{CO}_{2}+4 \mathrm{H}_{2} \rightarrow \mathrm{CH}_{4}+2 \mathrm{H}_{2} \mathrm{O}$

Hydrogen has the highest energy density $\left(142.35 \mathrm{~kJ} \mathrm{~g}^{-1}\right)$ in comparison with the all widely employed fuels such as gasoline, methane, diesel, kerosene, biodiesel, and ethanol. The amount of energy released in its combustion is about 3.0 times larger than gasoline, for example. Since the only product of its combustion is water, hydrogen is considered a clean and very promising energy source to replace fossil fuels [13].

The major motivation for biohydrogen production is the possibility of employing a wide variety of natural resources and organic wastes as either source of inoculum or substrates. Besides abundant, sewages from wastewater treatment systems have a great biological potential as inoculum, particularly in Brazil where the climate conditions are optimal for the activity of $\mathrm{H}_{2}$-producing bacteria [14]. However, to achieve these benefits and make it possible the development of more efficient conversion processes, it is essential the prior knowledge of biomass composition.

Thermal analysis stands out as a set of quantitative, reproductive, fast, and versatile techniques [15], wherein it is possible the characterization of biomass by direct measurement without requiring long periods of preparation. Thermogravimetry has proved to be a very useful technique to predict the chemical and biological stability of composting residues [15-20], which is required when proposing their use as organic fertilizer in agriculture.

Thermogravimetry and differential thermal analysis are widely employed for biomass characterization [21-28], providing information that are imperative for their application as energy source. Therefore, the aim of this study was the application of thermal analysis techniques as tools for the characterization of anaerobic sludge from different wastewater treatment plants, to predict their potential reuse as inocula for biological production of hydrogen.

\section{Materials and methods}

\section{Inocula: source and thermal characterization}

The samples of inoculum were obtained from full-scale UASB (Upflow Anaerobic Sludge Blanket) reactors employed for the treatment of different types of wastewater: the first one (BW) is the wastewater from beer processing (Heineken brewery) at Araraquara (São Paulo, Brazil) and the second (WWTP) is the sanitary sewage of São José do Rio Preto (São Paulo, Brazil), a city of 442,500 inhabitants.

Previously to thermal characterization, the sludge samples was dried at $100 \pm 5{ }^{\circ} \mathrm{C}$ for $24 \mathrm{~h}$, crushed and sieved until a $425 \mu \mathrm{m}$ particle size. TG, DTG, and DTA curves 
were obtained in a Simultaneous thermal analyzer Model SDT-2960 (TA Instruments), by employing $7 \mathrm{mg}$ of sample in $\alpha$-alumina sample holder. The measurements were taken (in triplicate) under compressed air atmosphere $\left(100 \mathrm{~mL} \mathrm{~min}{ }^{-1}\right.$ ) with the heating rate of $20^{\circ} \mathrm{C} \mathrm{min}^{-1}$, from room temperature up to $800{ }^{\circ} \mathrm{C}$. The equipment was prior calibrated for baseline, mass, and temperature in the proper experimental conditions.

\section{Inocula: pre-treatment conditions and cellular enrichment}

To evaluate the potential for $\mathrm{H}_{2}$ generation of BW and WWTP, each sludge sample was previously inoculated $(20 \% \mathrm{v} / \mathrm{v})$ in anaerobic reactors $(100 \mathrm{~mL})$ filled with $50 \mathrm{~mL}$ of PYG culture medium comprised of: glucose, $10 \mathrm{~g} \mathrm{~L}^{-1}$; peptone, $5 \mathrm{~g} \mathrm{~L}^{-1}$, yeast extract, $5 \mathrm{~g} \mathrm{~L}^{-1}$ and meat extract, $5 \mathrm{~g} \mathrm{~L}^{-1}$; $\mathrm{pH}$ 7.0). To establish the anaerobic environment, the headspace of reactors $(50 \mathrm{~mL})$ was filled with $\mathrm{N}_{2}(100 \%)$. These systems were maintained at $37^{\circ} \mathrm{C}$ for 7 days and then subjected to heat

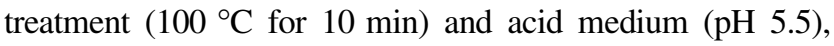
to inhibit the methanogenic activity and select endosporeproducing microorganisms [29].

The heat-treated inocula were purified using serial dilutions $(1 / 10)$ in batch anaerobic reactors containing PYG media $(\mathrm{pH}$ 5.5 , at $37^{\circ} \mathrm{C}$ ), which were maintained under anaerobic conditions for 7 days. After confirmed the hydrogen producers' activity and the absence of methane in the headspace of reactors by gas chromatography, the enriched inocula were centrifuged (9000 rpm at $4{ }^{\circ} \mathrm{C}$, for $5 \mathrm{~min}$ ).

Samples with $10 \mathrm{~mL}$ of cellular suspension of each inoculum were activated separately in anaerobic reactors (2L) containing $1 \mathrm{~L}$ of Del Nery culture medium [30], with the following composition (expressed in $\mathrm{mg} \mathrm{L}^{-1}$ ): sucrose (2000), peptone (1000), urea (40.0) e $2.5 \mathrm{~mL} \mathrm{~L}^{-1}$ of solutions A, B, C and D, which are: $\mathrm{A}-\mathrm{NiSO}_{4} \cdot 6 \mathrm{H}_{2} \mathrm{O}(0.50)$; $\mathrm{FeSO}_{4} \cdot 7 \mathrm{H}_{2} \mathrm{O} \quad(2.5) ; \quad \mathrm{FeCl}_{3} \cdot 6 \mathrm{H}_{2} \mathrm{O} \quad(0.25) ; \quad \mathrm{CoCl}_{2} \cdot 2 \mathrm{H}_{2} \mathrm{O}$ (0.04); $\mathrm{B}-\mathrm{CaCl}_{2} \cdot 6 \mathrm{H}_{2} \mathrm{O}$ (2.06); $\mathrm{C}-\mathrm{SeO}_{2}$ (0.14); $\mathrm{D}-\mathrm{KH}_{2} \mathrm{PO}_{4}$ (5.36); $\mathrm{K}_{2} \mathrm{HPO}_{4}$ (1.30); $\mathrm{Na}_{2} \mathrm{HPO}_{4} \mathrm{H}_{2} \mathrm{O}$ (2.76). In addition, $2.5 \mathrm{~mL} \mathrm{~L}^{-1}$ of $\mathrm{B}_{12}$ vitamin solution $\left(0.04 \mathrm{~g} \mathrm{~L}^{-1}\right)$ [31], p-amino benzoic acid $\left(0.04 \mathrm{~g} \mathrm{~L}^{-1}\right)$, and biotin $\left(0.01 \mathrm{~g} \mathrm{~L}^{-1}\right)$ were added to supplement the synthetic medium [29], with initial $\mathrm{pH}$ adjusted to 5.5. The headspace (1L) was filled with $\mathrm{N}_{2}(100 \%)$ for $20 \mathrm{~min}$, and the anaerobic reactors were incubated at $37{ }^{\circ} \mathrm{C}$ for $72 \mathrm{~h}$.

\section{Operation of Batch anaerobic reactors for biological production of $\mathrm{H}_{2}$}

After activation step, the adapted inocula were separated by centrifugation ( $9000 \mathrm{rpm}$ at $4{ }^{\circ} \mathrm{C}$, for $5 \mathrm{~min}$ ) and the resulting biomass, in each case, was inoculated separately in anaerobic reactors $(2 \mathrm{~L})$, containing $1 \mathrm{~L}$ of Del Nery culture medium ( $\mathrm{pH} 5.5$ ), which composition was previously described, and $1 \mathrm{~L}$ of headspace $\left(\mathrm{N}_{2}, 100 \%\right)$. The batch tests with each residue were performed in duplicate. The anaerobic reactors were maintained at $37^{\circ} \mathrm{C}$ throughout the period of tests monitoring.

\section{Chemical and chromatographic analysis}

The consumption of sucrose was evaluated through a phenol-sulfuric acid colorimetric method, according to Maintinguer et al. [14]. The $\mathrm{pH}$ measurements of substrates were taken at the beginning and end of testing. The initial $\mathrm{pH}$ was adjusted to 5.5 with additions of $\mathrm{HCl}\left(1.0 \mathrm{~mol} \mathrm{~L}{ }^{-1}\right)$ or $\mathrm{NaOH}\left(1.0 \mathrm{~mol} \mathrm{~L}^{-1}\right)$ since it is an appropriate value to avoid methanogenesis [32]. The cellular growth of inocula was monitored through optical density at $600 \mathrm{~nm}\left(\mathrm{OD}_{600}\right)$ [33] and expressed as volatile suspended solids (VSS, $\mathrm{g} \mathrm{L}^{-1}$ ), by Eq. (2) [14].

$\mathrm{VSS}=0.7436^{*} A B S_{600 \mathrm{~nm}}+0.0146$

The simultaneous determination of methane, hydrogen, and carbon dioxide present in biogas of anaerobic reactors was performed in a single chromatographic run, using a TOGA (Transformer Oil Gas Analyzer) system coupled with TRACE ${ }^{\mathrm{TM}}$ GC Ultra, Ultra Gas Chromatograph (Thermo Scientific) equipped with split/splitless injector, thermal conductivity detector (TCD) and ionization detector (FID), with methanizer.

After collected, the fraction of biogas $(0.1 \mathrm{~mL})$ containing hydrogen, nitrogen, and methane were analyzed using an RT-MSieve $5 \mathrm{~A}^{\circ}$ column $(30 \mathrm{~m} \times 0.53 \mathrm{id})$ and the carbon dioxide was analyzed by a Carboxen 1006 plot column $(30 \mathrm{~m} \times 0.53 \mathrm{~mm}$ id $)$. Hydrogen and nitrogen were analyzed by TCD. Methane and carbon dioxide were analyzed by FID, after passing through the methanizer. The complete oven programming was performed as it follows: $50{ }^{\circ} \mathrm{C}$ (4.5 min), followed by heating at $40{ }^{\circ} \mathrm{C} \min ^{-1}$ up to $180{ }^{\circ} \mathrm{C}$ (1 $\left.5 \mathrm{~min}\right)$ and cooling at $50{ }^{\circ} \mathrm{C} \min ^{-1}$ up to $50{ }^{\circ} \mathrm{C}$ (3.15 min). TCD Injector was programmed for $150{ }^{\circ} \mathrm{C}$ and FID detector, for $250{ }^{\circ} \mathrm{C}$. Argon was used as carrier gas, with a flow of $1.5 \mathrm{~mL} \mathrm{~min}^{-1}$, in splitless mode.

Measurements of the by-products from hydrogen generation, such as volatile fatty acids, were taken in accordance with [34], using a GC-2010 (Shimadzu) gas chromatograph equipped with FID and AOC 5000 autosampler (COMBI-PAL), using an HP-INNOWAX $(30 \mathrm{~m} \times 0.25 \mathrm{~mm} \times 0.25 \mu \mathrm{m})$ capillary column (Agilent Technologies).

\section{Experimental data adjustment}

The mean values obtained during batch tests with each inoculum were adjusted by employing the modified 
Gompertz function, Eq. (3) [35], with the assistance of Statistica ${ }^{\circledR}$ Software (version 8).

$H=P \cdot \exp \left\{-\exp \left[\frac{R_{\mathrm{m}} \cdot e}{P}(\lambda-t)+1\right]\right\}$

where $P$ is the hydrogen production potential $\left(\mathrm{mmol} \mathrm{L}^{-1}\right.$ of culture), $R_{\mathrm{m}}$ is the maximum hydrogen production rate (mmol L $\mathrm{L}^{-1}$ of culture $\mathrm{h}^{-1}$ ), and $\lambda$ is the lag phase (h), which precedes the activity of $\mathrm{H}_{2}$-producing consortia, in each test.

\section{Hydrogen-producing bacteria count by Most Probable Number (MPN) technique}

Most probable number (MPN) of total anaerobic bacteria and hydrogen-producing bacteria was evaluated (in triplicate) at the end of the test, using serial dilutions of each inoculum in anaerobic reactors $(100 \mathrm{~mL})$, containing $50 \mathrm{~mL}$ of PYG medium (pH 7.0), under aseptic conditions. Counts of total anaerobic bacteria were performed by culture turbidity (cells $100 \mathrm{~mL}^{-1}$ ), based on Standard Probability Table [33]. $\mathrm{H}_{2}$-producing bacteria, however, were evaluated after 10 days of incubation at $37^{\circ} \mathrm{C}$ for the presence (or absence) of $\mathrm{H}_{2}$ in the headspace of anaerobic reactors, using the gas chromatography methodology previously described.

\section{Morphologic characterization of inocula by Scanning Electron Microscopy (SEM)}

Morphological characterization of sludge samples was performed by SEM, using the TOP CON SM-300 microscope. Previously to microscopic analyses, the samples were covered with a thin gold layer in BALTEC SCD 050 equipment. Different regions of samples were explored, with 500 times and 3000 times $(1 \mu \mathrm{m})$ magnification, using an electric potential difference of $2 \mathrm{kV}$.

\section{Results and discussion}

TG, DTG, and DTA curves of sample BW and WWTP are presented in Fig. 1a and b, respectively. Both samples showed very similar decomposition profiles, with two major events of mass loss. The first event (1), responsible for the mass loss of $3.5 \%$ (BW) and $4.8 \%$ (WWTP), is attributed to the dehydration of residues.

The second and main event (2) observed occurs in two well-defined steps, between 150 and $550{ }^{\circ} \mathrm{C}$. This event is attributed to the combustion of organic matter present in samples, which is generated during biological treatment of the effluents and, therefore, mainly consists of cellular constituents of microorganisms resulting from each process of treatment [4].

Despite the similar decomposition intervals, sludge samples differ in amount (33.8 and 57.2\% for BW and WWTP, respectively), as well as in the type of organic matter content. This is clearly reflected by the shape and intensity of thermal events (DTG curves) as for the heat released during decomposition of the related organic components (DTA curves).

For both samples, combustion process presented two steps, starting with the release of the less stable organic compounds (devolatilization) as carbohydrates, amino acids, fatty acids, and other easily degradable organic compounds $[15,16]$. As decomposition starts and the temperature of system increases, the gaseous products reach their ignition, releasing significant amounts of heat [36]. It is the first step of organic matter decomposition, responsible for a significant loss of mass in both samples, $18 \%$ (BW) and 27\% (WWTP), which is represented by exothermic peaks in DTA curves around $300{ }^{\circ} \mathrm{C}$.

The loss of volatile organic matter generates the "biochar", a carbon residue resulting from the partial combustion of samples, which is associated with their inorganic components. The heat released during devolatilization promotes the combustion of biochar with subsequent formation of ashes; step observed from 350 to $550{ }^{\circ} \mathrm{C}$ for BW and from 334 to $527^{\circ} \mathrm{C}$ for WWTP, represented by exothermic peaks in $435^{\circ} \mathrm{C}$ (DTA curves) for both samples.

Since it is under a highly oxidizing atmosphere, all the steps comprising combustion process take place successively and are associated with many simultaneous transformations between organic and inorganic constituents [37]. Thus, as a very complex process, the extent of transformations and the type of products generated depends on either the original composition of biomass (organic and inorganic) or the heat released during its combustion.

Fernández et al. [15] observed profiles of mass loss and heat release similar to the obtained in the present study, applying synthetic air atmosphere. In the case of BW sample, the heat release profile presented two well-defined steps, which is quite similar to that reported for municipal solid waste submitted to the composting process. WWTP sample, instead, presented a decomposition profile closer to the reported for a heat-dried sludge sample that was not submitted to any process of anaerobic stabilization.

The authors above mentioned attributed to the presence of substances with high molecular weight, high stability and a high degree of aromaticity the intense exothermic peak close to $500{ }^{\circ} \mathrm{C}$. They observed a significant reduction in intensity of this peak after submitting the sludge sample to a biological stabilization process. 
Fig. 1 TG (dark line), DTG (dotted line) and DTA (dashed line) curves of anaerobic sludge samples a of brewery (BW) and b of municipal wastewater treatment plant (WWTP), employed for biological hydrogen production
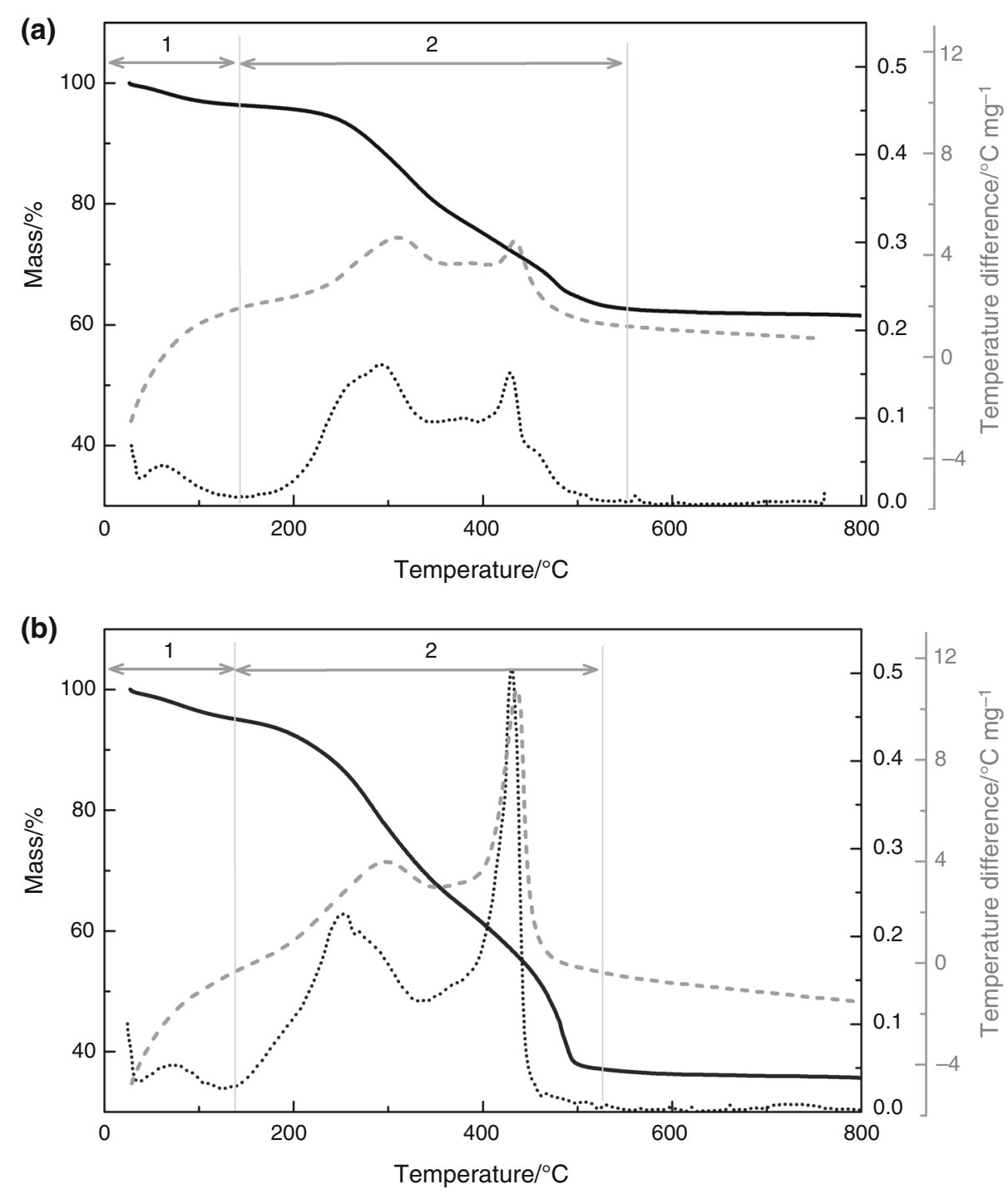

During the characterization of acetogenic anaerobic sludge employed for biogas production, Francioso et al. [38] also observed bimodal thermal decomposition profiles similar to the obtained for BW and WWTP samples. The authors described the first exothermic peak at $293{ }^{\circ} \mathrm{C}$ as a result of the decomposition of less stable compounds, such as carbohydrates and fatty acids, whereas the exothermic peak at $476{ }^{\circ} \mathrm{C}$ was attributed to the decomposition of organic compounds with a high degree of aromaticity.

The presence of thermally recalcitrant organic substances noted by the high-intensity exothermic peak around $500{ }^{\circ} \mathrm{C}$ may be an indicative of the sample stabilization degree. This property is very exploited [16-18] to predict the maturation of other residues as municipal solid wastes. The previous considerations are in agreement with the results reported by Gomez et al. [19], who studied the evolution of organic matter, during anaerobic digestion of sludge from different sources: pharmaceutical industry and cattle manure.
The relative amount of thermally stable organic matter and thermally labile organic matter may be employed as a parameter to describe the thermostability $(T s)$ of samples with high organic content such as sludge. The thermostability parameter may be calculated according to Eq. (4) [16], by the ratio between the mass losses (TG curves) associated with the second $\left(E x o_{2}\right)$ and the first $\left(E x o_{1}\right)$ exothermic event, regardless of moisture and ash content of the sample.

$T s=\frac{\Delta m E x o_{2}}{\Delta m E x o_{1}}$

Among the evaluated samples, WWTP showed higher thermostability (1.15) in relation to BW (0.91), which is due to its highest degree of stabilization elucidated by the sharp exothermic peak at $435{ }^{\circ} \mathrm{C}$ coupled with the biggest mass loss $(30.2 \%)$ throughout the thermal event of char combustion (Fig. 1b). The higher thermostability of 
WWTP suggests the better performance of the anaerobic process from which this sample was generated.

On the other hand, the largest amount of readily biodegradable organic matter in WWTP sludge (27\%), probably from bacterial cells [16] suggests its higher cellular density and, therefore, their higher viability to perform the anaerobic hydrogen production.

During batch tests, it was found that both inocula had potential for $\mathrm{H}_{2}$ production after being subjected to heat pre-treatment and cell enrichment. All data concerning the tests for $\mathrm{H}_{2}$ production are summarized in Table 1 .

Despite requiring a longer period of adaptation after the pre-treatment procedure $(22 \mathrm{~h}$ of lag phase), WWTP inoculum presented a hydrogen production potential, which was $78 \%$ greater $\left(8.0 \mathrm{mmol} \mathrm{H}_{2} \mathrm{~L}^{-1}\right.$ substrate) than $\mathrm{BW}$ inoculum (4.5 mmol $\mathrm{H}_{2} \mathrm{~L}^{-1}$ substrate) (Fig. 2), in same operational conditions.

Also, the cellular growth of WWTP inoculum was about three times bigger in the same period. These findings corroborate the information previously obtained in the thermal characterization of inocula.

For the biological production of $\mathrm{H}_{2}$ [28] operated batch anaerobic reactors, employing as inoculum a granular sludge (UASB reactors) from swine wastewaters treatment,

Table 1 Summary of the results obtained during batch test for hydrogen production, employing anaerobic sludge samples BW and WWTP

\begin{tabular}{|c|c|c|}
\hline \multirow[t]{2}{*}{ Operational parameters } & \multicolumn{2}{|l|}{ Samples } \\
\hline & BW & WWTP \\
\hline Sucrose/g L ${ }^{-1}$ & 2.0 & 2.0 \\
\hline Operation time/h & 166.5 & 173.5 \\
\hline Cellular grow/g L $\mathrm{L}^{-1 \mathrm{a}}$ & 0.15 & 0.4 \\
\hline Sucrose consumption/\% & 88.7 & 75.0 \\
\hline$P / \mathrm{mmol} \mathrm{H}_{2} \mathrm{~L}^{-1 \mathrm{~b}_{*}}$ & 4.5 & 8.0 \\
\hline$R m / \mathrm{mmol} \mathrm{H}_{2} \mathrm{~L}^{-1}$ culture $\mathrm{h}^{-1 \mathrm{c} *}$ & 0.2 & 0.4 \\
\hline Lag phase/h* & 13.0 & 22.0 \\
\hline Period $/ h^{\mathrm{d}}$ & 52.0 & 49.0 \\
\hline $\mathrm{H}_{2}$ yield/mol $\mathrm{H}_{2} \mathrm{~mol}^{-1}$ sucrose & 0.9 & 2.0 \\
\hline Overall yield/\% & 10.8 & 25.0 \\
\hline \multicolumn{3}{|l|}{ By-products/mg L ${ }^{-1}$} \\
\hline Acetic acid & 18.0 & 173.0 \\
\hline Butyric acid & 106.0 & 234.0 \\
\hline Initial $\mathrm{pH}$ & 5.5 & 5.5 \\
\hline Final pH & 4.4 & 3.3 \\
\hline
\end{tabular}

${ }^{a}$ Expressed as VSS, volatile suspended solids

${ }^{b}$ Highest $\mathrm{H}_{2}$ production

c Maximum production rate

${ }^{d}$ Period to reach the highest $\mathrm{H}_{2}$ production

* Parameters calculated from modified Gompertz function

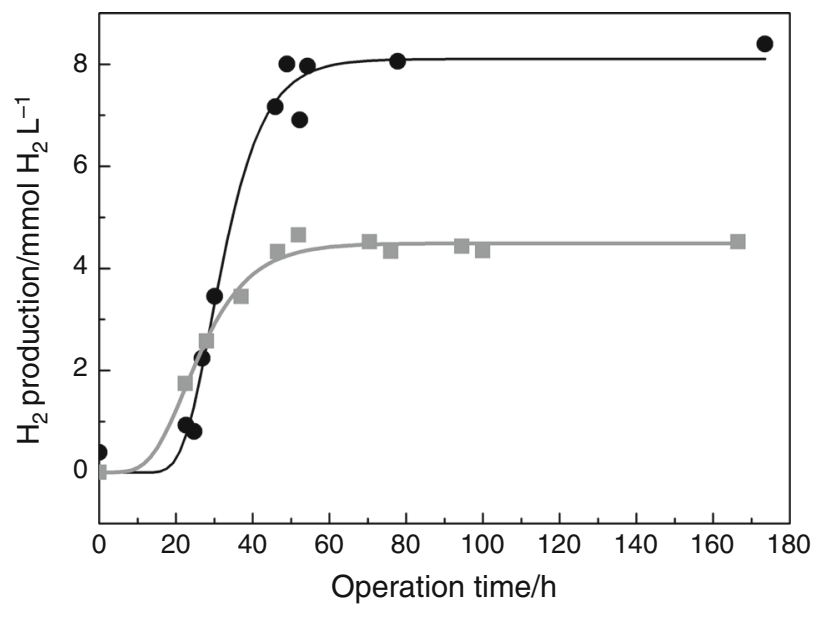

Fig. 2 Hydrogen production from BW (filled square) and WWTP (filled circle) sludge samples, during anaerobic batch tests with $2 \mathrm{~g} \mathrm{~L}^{-1}$ of sucrose in synthetic culture media

with the same pre-treatment conditions. In tests with a concentration of sucrose close to the applied in the present study, the authors obtained maximum $\mathrm{H}_{2}$ production of $1.2 \mathrm{~mol} \mathrm{H}_{2} \mathrm{~mol}^{-1}$ sucrose, corresponding to an efficiency of $15 \%$ in sucrose conversion of sucrose, below the obtained for WWTP inoculum.

Using mixed anaerobic cultures, Fang and Liu [32] obtained a hydrogen yield $\left(2.1 \mathrm{~mol} \mathrm{H}_{2} \mathrm{~mol}^{-1}\right.$ glucose $)$ close to the obtained for WWTP inoculum, by employing similar operational conditions: $\mathrm{pH} 5.5$ at $36{ }^{\circ} \mathrm{C}$. A similar performance in $\mathrm{H}_{2}$ production (2.18 mol $\mathrm{H}_{2} \mathrm{~mol}^{-1}$ glucose) was also observed by anaerobically digested sludge [39] in mesophilic conditions, which were higher when compared with the activated sludge $\left(0.56 \mathrm{~mol} \mathrm{H}_{2} \mathrm{~mol}^{-1}\right.$ glucose $)$ evaluated by the same authors.

The energy efficiency of sucrose conversion, in other words, the overall yield of the fermentation process, may be calculated taking into account the relation between carbohydrate consumption and production of $\mathrm{H}_{2}$, according to Eq. (5) [40]:

Yield $(\%)=\left(\frac{\frac{\text { mol of } \mathrm{H}_{2} \text { produced }}{\text { mol of carbohydrate consumed }}}{\frac{\text { maximum theoretical production of } \mathrm{H}_{2}}{\text { mol of carboydrate in substrate }}}\right) \times 100 \%$

For conversion of $1 \mathrm{~mol}$ of sucrose, the theoretical maximum production of $\mathrm{H}_{2}$ is $8 \mathrm{~mol}$, with the joint generation of 4 mol of acetic acid and 4 mol of carbon dioxide, according to Eq. (6) [41]:

$\mathrm{C}_{12} \mathrm{H}_{22} \mathrm{O}_{11}+5 \mathrm{H}_{2} \mathrm{O} \rightarrow 4 \mathrm{CH}_{3} \mathrm{COOH}+4 \mathrm{CO}_{2}+8 \mathrm{H}_{2}$

Considering the maximum production of $\mathrm{H}_{2}$, calculated by Eq. (3), the overall yield for sucrose conversion (from 
Eq. 5) was 10.8 and $25.0 \%$ for inocula BW and WWTP, respectively (Table 1$)$.

According to Eq. (6), the theoretical maximum production of $\mathrm{H}_{2}$ leads to the generation of acetic acid [41]. Thus, this by-product may be used as an indicator that the higher yield metabolic pathway took place during the fermentative production of $\mathrm{H}_{2}$. In practice, however, the high production of $\mathrm{H}_{2}$ is commonly associated with a mixture of acetic acid and butyric acid, whose formation is given by Eq. (7).

$$
\begin{aligned}
\mathrm{C}_{12} \mathrm{H}_{22} \mathrm{O}_{11}+\mathrm{H}_{2} \mathrm{O} \rightarrow & 2 \mathrm{CH}_{3} \mathrm{CH}_{2} \mathrm{CH}_{2} \mathrm{COOH}+4 \mathrm{CO}_{2} \\
& +4 \mathrm{H}_{2}
\end{aligned}
$$

The low production of $\mathrm{H}_{2}$, instead, results from the formation of other by-products such as propionic acid, alcohol, and lactic acid [10, 42] since these metabolic pathways occur from the consumption of $\mathrm{H}_{2}$.

Acetic acid and butyric acids were the main by-products generated during the fermentative $\mathrm{H}_{2}$ production with the different inocula here evaluated (Table 1). The generation of these metabolites led to a depletion in buffering capacity of culture media [41], resulting in a decrease in $\mathrm{pH}$ throughout the operation of anaerobic reactors, which changed from 5.5 to 4.4 (BW) and 3.3 (WWTP) up to the end of tests, 166.5 and $173.5 \mathrm{~h}$, respectively.

As noted, the highest production of the volatile fatty acids in tests with WWTP contributed to the most pronounced reduction in $\mathrm{pH}$ (from 5.5 to 3.3). Nevertheless, it is associated with the highest production of $\mathrm{H}_{2}$ by the same inoculum, which is confirmed by chromatographic analyses (Fig. 2).

As mentioned by Kapdan and Kargi [11], evaluations concerning the microbial diversity of $\mathrm{H}_{2}$-producing bacterial consortia revealed the predominance of Clostridia species $(64.6 \%)$, after the thermal pre-treatment followed by reactivation of inoculum in proper environmental conditions. These species produces $\mathrm{H}_{2}$ and organic acids as acetic acid, butyric acid and propionic acid, during the exponential phase of cellular growth and are probably involved in fermentative processes developed from both residues.

The bacteria count by MPN technique (Fig. 3) showed higher amounts of total anaerobic bacteria in sample BW $\left(2.10^{10} \mathrm{MPN} 100 \mathrm{~mL}^{-1}\right)$ when compared with WWTP sample $\left(1.10^{10}\right.$ MPN $\left.100 \mathrm{~mL}^{-1}\right)$. However, it was verified the predominance of $\mathrm{H}_{2}$-producing bacteria in WWTP $\left(1.10^{10} \mathrm{MPN} 100 \mathrm{~mL}^{-1}\right)$, which was 4.6 thousand times the amount of $\mathrm{H}_{2}$-producing bacteria present in BW $\left(2.10^{6}\right.$ MPN $100 \mathrm{~mL}^{-1}$ ). These findings explain the higher potential of WWTP inoculum for $\mathrm{H}_{2}$ production and clearly demonstrate the different composition of both residues.

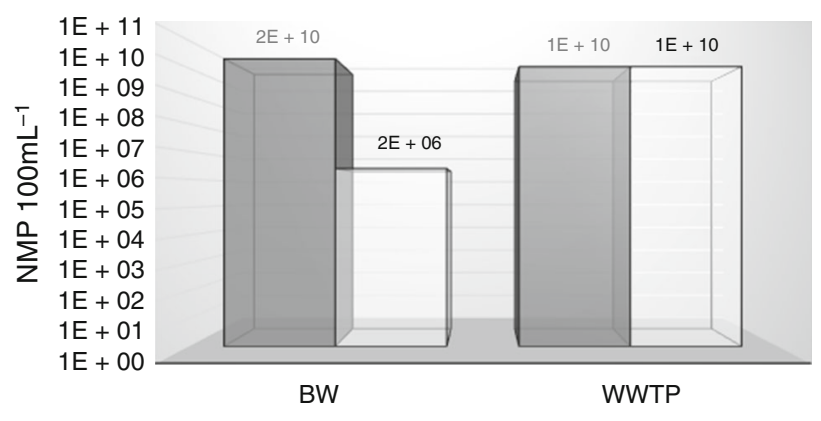

Fig. 3 Count of total anaerobic bacteria (filled square) and hydrogenproducing bacteria (open square) present in BW and WWTP samples

These differences are directly related to the composition of their generating sources and corroborate with the thermal characterization of samples performed by TG and DTA techniques that previously elucidate the higher cellular density and the higher compositional diversity of WWTP inoculum.

Furthermore, using a more in-depth analysis of TG and DTA curves (Fig. 1), it is possible to note the higher amount of ash present in BW sludge $(62.7 \%)$ compared to WWTP sludge (38.0\%). It may also be a key factor to justify the lower yield in $\mathrm{H}_{2}$ production of $\mathrm{BW}$ inoculum since these inorganic compounds might cause toxicity to $\mathrm{H}_{2}$-producing bacterial consortia.

The morphological characterization of samples revealed the prevalence of diatomites in the brewery sludge (BW) (Fig. 4a). Diatomite is the remains skeletal of single-cell water plants (algae) composed mainly of silica (up to $90 \%$ ), which is used in a powdered form as the nonmetallic mineral known as diatomaceous earth. As can be seen in Fig. $4 \mathrm{~b}$, the structure of diatomite has numerous fine microscopic pores, cavities, and channels, which results in a material with small particle size, high porosity, high specific surface area, low specific gravity and, therefore, high adsorption capacity [43, 44].

These properties make diatomaceous earth an excellent filter-aid widely applied in clarification of rough beer, one of the most critical operations in the brewing process. It probably explains a large amount of diatomite observed in BW sludge.

Approximately $67 \%$ of the diatomaceous earth production is used in beverage industry (beer, wine, fruit juice). Only in Europe, the use of diatomaceous earth is around $1.7 \mathrm{~g}$ per liter of clarified beer. At the end of the filtration process, diatomaceous earth sludge more than tripled in weight making its disposal the major difficulty of the process due to its polluting feature as well as its high cost [6].

Despite the lower potential for $\mathrm{H}_{2}$ production in relation to WWTP, BW sludge presented a better performance than other anaerobic sludge applied for this purpose to different 
Fig. 4 Morphologic characterization of BW sludge by scanning electron microscopy a predominance of diatomites and $\mathbf{b}$ expansion of diatomite image, focusing on the presence of bacilli over this structure
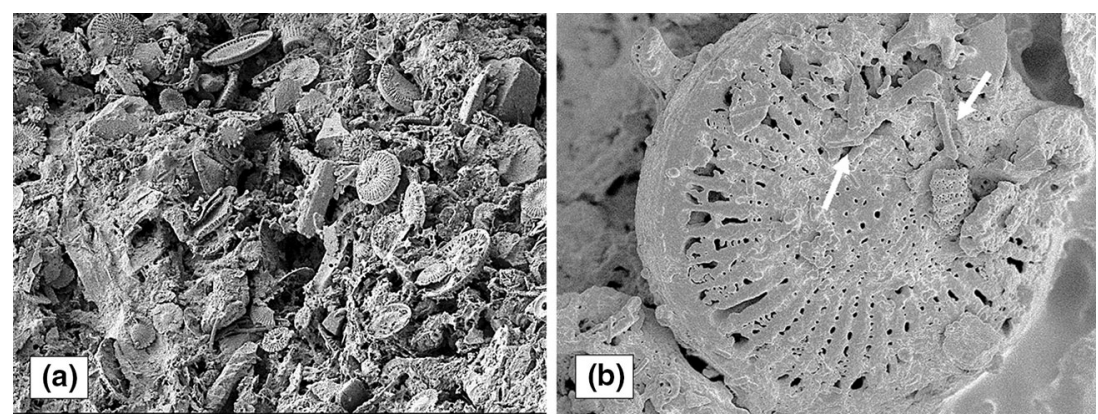

types of substrates and wastewaters (in similar operational conditions), such as wastewater from cereal production, coffee drink manufacturing wastewater, wastewater with condensed molasses and citric acid wastewater [45]. It may be due to the type of anaerobic process applied to treat the brewery effluents that promoted the development of a large number of anaerobic bacteria and, among them, the $\mathrm{H}_{2}$-producing bacteria.

In Fig. 4b is pointed out the presence of bacilli, a morphology particular of $\mathrm{H}_{2}$-production bacteria, associated with the structure of diatomite. Therefore, $\mathrm{H}_{2}$ production using anaerobic digestion may represent a more cost-effective solution for diatomaceous earth sludge disposal.

\section{Conclusions}

Both sludge samples have potential for biological hydrogen generation. The sample from the municipal wastewater treatment plant showed higher yield in the fermentative process for generation of this biogas due to the predominance of $\mathrm{H}_{2}$-producing bacteria in this residue, in comparison with the sludge of brewery industry.

Thermal characterization performed by TG and DTA techniques supplied an indicator of the biological potential of each residue; corroborating the results of $\mathrm{H}_{2}$ production further obtained using anaerobic batch tests. These results demonstrate the functionality and versatility of thermal analysis techniques as tools for biomass characterization, while proving the potential reuse of these residues as inoculum sources to obtain clean energy.

Acknowledgements The authors would like to thank Fundação de Amparo à Pesquisa do Estado de São Paulo (FAPESP-Proc. 2012/01318-1), Fundação para o Desenvolvimento da Unesp (Fundunesp) and Coordenação de Aperfeiçoamento de Pessoal de Nível Superior (CAPES). We are also grateful to Heineken (Araraquara) and SeMaE (São José do Rio Preto) for the provision of sludge samples and the LMA-IQ for SEM facilities.

\section{References}

1. Brazil. Ministry of the Environment. National Council of the Environment. In: Resolution no 357 of March 17, 2005. 2005. http://www.mma.gov.br/port/conama/res/res05/res35705.pdf. Accessed 10 Feb 2016.

2. International water law project. In: International documents. 2016. http://www.internationalwaterlaw.org/documents/intldocs/. Accessed 18 May 2016.

3. Rulkens W. Sewage sludge as a biomass resource for the production of energy: overview and assessment of the various options. Energ Fuel. 2008;22(1):9-15.

4. Tyagi VK, Lo S-L. Sludge: a waste or renewable source for energy and resources recovery? Renew Sustain Energy Rev. 2013;25:708-28.

5. Brazil. Law no 12,305, of August 2, 2010. Establishing the national solid waste policy, alters the Law no. 9605, of February 12, 1998, among other provisions. Diário Oficial da União, Brasília, DF, August 2, 2010. http://www.planalto.gov. br/ccivil_03/_ato2007-2010/2010/lei/112305.htm. Accessed 20 Apr 2016.

6. Fillaudeau L, Boissier B, Moreau A, Blanpain-avet P, Ermolaev $\mathrm{S}$, Jitariouk $\mathrm{N}$, Gourdon A. Investigation of rotating and vibrating filtration for clarification of rough beer. J Food Eng. 2007;80(1): 206-17.

7. The Statistic Portal. Beer production worldwide from 1998 to 2014 (in billion hectoliters). 2016. http://www.statista.com/statis tics/270275/worldwide-beer-production/. Accessed 18 May 2016.

8. Ni M, Leung DYC, Leung MKH, Sumathy K. An overview of hydrogen production from biomass. Fuel Process Technol. 2006;87(5):461-72.

9. Saady NMC. Homoacetogenesis during hydrogen production by mixed cultures dark fermentation: unresolved challenge. Int $\mathrm{J}$ Hydrogen Energ. 2013;38(30):13172-91.

10. Angenent LT, Karim K, Al-Dahhan MH, Wrenn BA, DomiguezEspinosa R. Production of bioenergy and biochemicals from industrial and agricultural wastewater. Trends Biotechnol. 2004;22(9):477-85.

11. Kapdan IK, Kargi F. Bio-hydrogen production from waste materials. Enzyme Microb Tech. 2006;38(5):569-82.

12. Wong YM, Wu TY, Juan JC. A review of sustainable hydrogen production using seed sludge via dark fermentation. Renew Sust Energ Rev. 2014;34:471-82.

13. Guo XM, Trably E, Latrille E, Carrère H, Steyer J-P. Hydrogen production from agricultural waste by dark fermentation: a review. Int J Hydrogen Energ. 2010;35(19):10660-73.

14. Maintinguer SI, Sakamoto IK, Adorno MAT, Varesche MBA. Bacterial diversity from environmental sample applied to biohydrogen production. Int $\mathbf{J}$ Hydrogen Energ. 2015;40(8): 3180-90. 
15. Fernández JM, Plaza C, Polo A, Plante AF. Use of thermal analysis techniques (TG-DSC) for the characterization of diverse organic municipal waste streams to predict biological stability prior to land application. Waste Manage. 2012;32(1):158-64.

16. Baffi C, Dell'Abate MT, Nassisi A, Silva S, Benedetti A, Genevini PL, Adani F. Determination of biological stability in compost: a comparison of methodologies. Soil Biol Biochem. 2007;39(6):1284-93.

17. Smidt E, Lechner P. Study on the degradation and stabilization of organic matter in waste by means of thermal analyses. Thermochim Acta. 2005;438(1-2):22-8.

18. Pietro M, Paola C. Thermal analysis for the evaluation of the organic matter evolution during municipal solid waste aerobic composting process. Thermochim Acta. 2004;413(1-2):209-14.

19. Gómez X, Cuetos MJ, García AI, Morán A. An evaluation of stability by thermogravimetric analysis of digestate obtained from different biowastes. J Hazard Mater. 2007;149(1):97-105.

20. Castaldi P, Alberti G, Merella R, Melis P. Study of the organic matter evolution during municipal solid waste composting aimed at identifying suitable parameters for the evaluation of compost maturity. Waste Manage. 2005;25(2):209-13.

21. Munir S, Daood SS, Nimmo W, Cunliffe AM, Gibbs BM. Thermal analysis and devolatilization kinetics of cotton stalk, sugar cane bagasse and shea meal under nitrogen and air atmospheres. Bioresource Technol. 2009;100(3):1413-8.

22. Barneto AG, Carmona JA, Alfonso JEM, Blanco JD. Kinetic models based in biomass components for the combustion and pyrolysis of sewage sludge and its compost. J Anal Appl Pyrol. 2009;86(1):108-14.

23. Carrier M, Loppinet-Serani A, Denux D, Lasnier J-M, HamPichavant F, Cansell F, Aymonier C. Thermogravimetric analysis as a new method to determine the lignocellulosic composition of biomass. Biomass Bioenerg. 2011;35(1):298-307.

24. Pécora AAB, Ávila I, Lira CS, Cruz G, Crnkovic PM. Prediction of the combustion process in fluidized bed based on physicalchemical properties of biomass particles and their hydrodynamic behaviors. Fuel Process Technol. 2014;124:188-97.

25. Saldarriaga JF, Aguado R, Pablos A, Amutio M, Olazar M, Bilbao J. Fast characterization of biomass fuels by thermogravimetric analysis (TGA). Fuel. 2015;140:744-51.

26. Lai Z, Ma X, Tang Y, Lin H, Chen Y. Thermogravimetric analyses of combustion of lignocellulosic materials in $\mathrm{N}_{2} / \mathrm{O}_{2}$ and $\mathrm{CO}_{2} / \mathrm{O}_{2}$ atmospheres. Bioresource Technol. 2012;107:444-50.

27. Cruz G, Crnkovic PM. Investigation into the kinetic behavior of biomass combustion under $\mathrm{N}_{2} / \mathrm{O}_{2}$ and $\mathrm{CO}_{2} / \mathrm{O}_{2}$ atmospheres. J Therm Anal Calorim. 2016;123(2):1003-11.

28. Guida MY, Bouaik H, Tabal A, Hannioui A, Solhy A, Barakat A, Aboulkas A, El harfi K. Thermochemical treatment of olive mill solid waste and olive mill wastewater. J Therm Anal Calorim. 2016;123(2):1657-66.

29. Maintinguer SI, Fernandes BS, Duarte ICS, Saavedra NK, Adorno MAT, Varesche MB. Fermentative hydrogen production by microbial consortium. Int J Hydrogen Energ. 2008;33(16): 4309-17.
30. Del Nery, V. Use of anaerobic sludge immobilized in gel in the study of the departure of reactors with upflow sludge blanket. Thesis (Masters). Engineering School of São Carlos, São Paulo University; 1987 ["In portuguese"].

31. Lazaro CZ, Vich DV, Hirasawa JS, Varesche MBA. Hydrogen production and consumption of organic acids by a phototrophic microbial consortium. Int J Hydrogen Energ. 2012;37(16): 11691-700.

32. Fang HHP, Liu H. Effect of $\mathrm{pH}$ on hydrogen production from glucose by a mixed culture. Bioresource Technol. 2002;82(1):87-93.

33. APHA-AWWA-WEF. Standard methods for the examination of water and wastewater. 21st ed. Washington, DC, USA: American Public Health Association, American Water Works Association, Water Environmental Federation. 2005. https://www.standard methods.org/. Accessed 28 May 2016.

34. Adorno MAT, Hirasawa JS, Varesche MBA. Development and validation of two methods to quantify volatile acids (C2-C6) by GC/FID: headspace (automatic and manual) and liquid-liquid extraction (LLE). Am J Anal Chem. 2014;05(07):406-14.

35. Lay J-J, Li Y-Y, Noike T. Developments of bacterial population and methanogenic activity in a laboratory-scale landfill bioreactor. Water Res. 1998;32(12):3673-9.

36. Torquato LM, Braz CEM, Ribeiro CA, Capela JMV, Crespi MS. Kinetic study of the co-firing of bagasse-sludge blends. J Therm Anal Calorim. 2015;121(1):499-507.

37. Vassilev SV, Baxter D, Vassileva CG. An overview of the behaviour of biomass during combustion: part I. Phase-mineral transformations of organic and inorganic matter. Fuel. 2013;112:391-449.

38. Francioso O, Rodriguez-Estrada MT, Montecchio D, Salomoni C, Caputo A, Palenzona D. Chemical characterization of municipal wastewater sludges produced by two-phase anaerobic digestion for biogas production. J Hazard Mater. 2010;175(1-3):740-6.

39. Baghchehsaraee B, Nakhla G, Karamanev D, Margaritis A. Fermentative hydrogen production by diverse microflora. Int $\mathrm{J}$ Hydrogen Energ. 2010;35(10):5021-7.

40. De Gioannis G, Muntoni A, Polettini A, Pomi R. A review of dark fermentative hydrogen production from biodegradable municipal waste fractions. Waste Manage. 2013;33(6):1345-61.

41. Khanal SK, Chen W-H, Li L, Sung S. Biological hydrogen production: effects of $\mathrm{pH}$ and intermediate products. Int J Hydrogen Energ. 2004;29:1123-31.

42. Levin DB, Pitt L, Love M. Biohydrogen production: prospects and limitations to practical application. Int J Hydrogen Energ. 2004;29(2):173-85.

43. Martinovic S, Vlahovic M, Boljanac T, Pavlovic L. Preparation of filter aids based on diatomites. Int $\mathrm{J}$ Miner Process. 2006;80(2-4):255-60.

44. Crangle Jr RD. Diatomite. In: 2013 Mineral Commodity Summaries. United States Geological Survey. 2014. http://minerals. usgs.gov/minerals/pubs/commodity/diatomite/mcs-2014-diato. pdf. Accessed 18 May 2016.

45. Lin C-Y, Lay C-H, Sen B, Chu C-Y, Kumar G, Chen C-C, Chang $\mathrm{J}-\mathrm{S}$. Fermentative hydrogen production from wastewaters: a review and prognosis. Int J Hydrogen Energ. 2012;37(20):15632-42. 